American Journal of Animal and Veterinary Sciences 6 (1): 55-58, 2011

ISSN 1557-4555

(C) 2011 Science Publications

\title{
The Effect of Ivermectin Pour-on Administration Against Natural Heterakis gallinarum Infestation and its Prevalence in Native Poultry
}

\author{
${ }^{1}$ M.H. Khayatnouri, ${ }^{2}$ Y. Garedaghi, ${ }^{3}$ A.R. Arbati and ${ }^{3}$ H. Khalili \\ ${ }^{1}$ Department of Pharmacology, \\ ${ }^{2}$ Department of Parasitology, \\ ${ }^{3}$ Faculty of Veterinary, \\ Tabriz Branch, Islamic Azad University, Tabriz, Iran
}

\begin{abstract}
Problem statement: One of the real problems that cause the economic prejudice in animal farms yearly is parasitic diseases. To overcome these problems the use of antiparasitic drugs is necessary. Ivermectin is a broad spectrum antiparasitic agent and different routes of its administration such as injection, oral and pour-on were used. The aims of the current study were evaluation of the efficacy of ivermectin pour-on administration against natural Heterakis gallinarum infection in native poultry and also determination the prevalence rate of this parasite in Tabriz area. Approach:In the present study, 120 native poultry were investigated by Egg Per Gram of feces (EPG) feces test. Willis method was applied for feces test and Mack-master slide method was used for counting nematode eggs. After confirming the infection with worms, Ivermectin $\left(0.5 \mathrm{mg} \mathrm{kg}^{-1}\right)$ pour-on was administrated to infected birds. Fecal examination was repeated in 1, 7, 21 and 28 days post treatment. Results: Results showed that total prevalence of Heterakis gallinarum infection was $21.66 \%$ in native poultry of Tabriz area. Efficacy rate of ivermectin pour-on was 59.14, 87.87, 97.65 and $99.57 \%$ in 1, 7, 21 and 28 days respectively. Conclusion: In conclusion, the effect of this drug against Heterakis gallinarum resulted in reduction in egg count exceeded $98 \%(\mathrm{p}<0.05)$, so this drug can be used in antiparasitic program in poultry. Further investigations are necessary to evaluate the drug effect on other nematodes and parasitic infections.
\end{abstract}

Key words: Parasitic diseases, fecal examination, parasitic drugs, topical formulations

\section{INTRODUCTION}

Infections with gastrointestinal nematodes are very common on native poultry in Iran and all over the world. Parasitic infections of poultry are major factors responsible for economic losses through reduction in productivity and increased mortality (Lund and Chute, 1974; Bhat and Hemaprasanth, 1990). Parasites cause the birds to be unthrifty which may include the loss of weight. Due to parasitism, the animals become susceptible to other health problems which can lead to death. Many researches for prevalence rate of gastrointestinal parasites all over the world have been reported but researches for effect of anti parasitic drugs by different administration routes is low and in Iran the study on present subject has not been done (Georgi and Georgi, 1990; Kassai, 1999; Mandal, 2006; Soulsby, 1986). Ivermectin is a member of the macrocyclic lactone class of endectocides. It is labeled for the treatment of internal and external parasites in dogs, cats, horses, pigs, sheep, cattle and birds. Subcutaneous and topical formulations are available for use in animals, at a dose of 0.2 and $0.5 \mathrm{mg} \mathrm{kg}^{-1}$ bodyweight, respectively. Ivermectin is a highly potent broadspectrum anthelmintic that is widely used in different animals. It is available in injectable, oral and topical formulations for use in animals (Vermunt et al., 1995; Williams et al., 1997). The most important GI nematode responsible for considerable production losses in poultry is Heterakis gallinarum (Lund and Chute, 1974). The objective of the present study is the evaluation of the effect of ivermectin pour-on administration against natural Heterakis gallinarum nematode infections and determination of its prevalence rate in native poultry. This study is the first report in Iran.

\section{MATERIALS AND METHODS}

In present study a total number of 120 native poultry to Heterakis gallinarum infestation, from 20

Corresponding Author: Khayatnouri Mirhadi, Department of Pharmacology, Tabriz Branch, Islamic Azad University, Tabriz, Iran 
American J. Animal \& Vet. Sci., 6 (1): 55-58, 2011

different farms in Tabriz area were subjected for fecal examination and EPG. Ivermectin was administrated to treat infected animals at a dose of $0.5 \mathrm{mg} \mathrm{kg}^{-1}$. Also pour- on form of $0.5 \%$ Ivermectin powder in Isopropyl alcohol was made. Before and after poultry treatment, 3 fecal samples of each animal were taken for fecal examination and egg count was recorded. Fecal examination in days $1,7,21$ and 28 after treatment were repeated. In the present study, Willis method for fecal examination and Mack-master slide method for egg examination (EPG) were used (Aguirre et al., 2005; Marley et al., 1993). Ivermectin efficacy was calculated according to the following equation: $\%$ of drug efficacy $=\mathrm{P}-\mathrm{R} / \mathrm{P} \times 100$ :

$\mathrm{R}=$ Average number of parasite egg in gr of fecal sample after treatment

$\mathrm{P}=$ Average number of parasite egg in gr of fecal sample before treatment

Data were analyzed by non-parametric crosscalwalis and $\mathrm{P}<0.05$ was considered significant.

\section{RESULTS}

The results of present study indicated that 26 birds from a total of 120 were infected with Heterakis gallinarum with a prevalence rate of $21.66 \%$. Average number of enumerated egg in infected non treated animals was 470 . The average number of enumerated egg in fecal samples after treatment with pour on Ivermectin has been shown in Table 1. Reduction percentages in egg count after 1, 7, 14 and 21 days of treatment with Ivermectin were 59.14, 87.87, 97.65 and 99.57 respectively (Table 1 ).

\section{DISCUSSION}

According to results of crosscal-walis test it is possible to determine which pour on administration of Ivermectin decreases the natural infestation of bird with Heterakis gallinarum. The efficacy rate of Ivermectin on this parasite is more than $98 \%$. Recently, Ivermectin has different drug shapes. Half time of intra venal administration of Ivermectin with dose of $300 \mu \mathrm{g} \mathrm{Kg}^{-1}$ in cattle is 2.8 day, but in subcutaneous administration with dose of $200 \mu \mathrm{g} \mathrm{Kg}^{-1}$ is 8 day and also has been shown that the effect of sustained-release administration of this drug in cattle is more than to oral and subcutaneous administration (Reinemeyer and Courtney, 2001), but in poultry any research was not done. The important base in use of antiparasitic drug is the increase of contact time of drugs with parasites rather than increase the dose of these drugs (Georgi and Georgi, 1990; Kassai, 1999; Reinemeyer and Courtney, 2001; Soulsby, 1986; Urquhart et al., 2003).
Table 1: Average number of egg in fecal samples before and after treatment with pour on Ivermectin and percentages of egg count reduction

\begin{tabular}{lllll}
\hline $\begin{array}{l}\text { Before } \\
\text { treatment }\end{array}$ & $\begin{array}{l}1 \text { day } \\
\text { after } \\
\text { treatment }\end{array}$ & $\begin{array}{l}7 \text { days } \\
\text { after } \\
\text { treatment }\end{array}$ & $\begin{array}{l}21 \text { days } \\
\text { after } \\
\text { treatment }\end{array}$ & $\begin{array}{l}28 \text { days } \\
\text { after } \\
\text { treatment }\end{array}$ \\
\hline 470 & 192 & 57 & 11 & 2 \\
& $(59.14 \%)$ & $(87.87 \%)$ & $(97.65 \%)$ & $(99.57 \%)$ \\
\hline
\end{tabular}

This subject has been demonstrated that Ivermectin with dose of $1 \mathrm{mg} \mathrm{kg}^{-1}$ (oral or injection) have effective antiparasitic role in veterinary. The dose of this drug in cattle for oral and subcutaneous administration is $0.2 \mathrm{mg}$ $\mathrm{kg}^{-1}$ and for pour on administration is $0.5 \mathrm{mg} \mathrm{kg}^{-1}$; these doses of Ivermectin have potent anthelmintic effect between $97-100 \%$ on adult form and forth stage larvae of Haemonchus, Ostertagia, Cooperia, Trichostrongylus, Strongyloides, Bonostomum, Nematodirus, Trichuris, Oesophagostomum, Dictyocaulus and Chabertia ovina and some arthropods (Georgi and Georgi, 1990; Kassai, 1999; Reinemeyer and Courtney, 2001; Soulsby, 1986; Urquhart et al., 2003), therefore we administrated ivermectin pour on with $0.5 \mathrm{mg} \mathrm{kg}^{-1}$ dosage in poultry. According to findings of previous researches, tablet form of Ivermectin with dose of $0.4 \mathrm{mg} \mathrm{kg}^{-1}$ causes reduce in eggs in feces during 10 week after treatment but has not protective role for reinfection of cattle (Egerton et al., 1981; Gary and Kumar, 2007; Reinemeyer and Courtney, 2001). Subcutaneous administration of Ivermectin with dose of $0.2 \mathrm{mg} \mathrm{kg}^{-1}$ and pour on of that with $0.5 \mathrm{mg} \mathrm{kg}^{-1}$ dose, have high effective role for control of parasites, also have important protective role for reinfection in cattle. Also according to findings of researchers, administration of Ivermectin with dose of $0.5 \mathrm{mg} \mathrm{kg}^{-1}$ has high effect between $95-100 \%$ on Haemonchus, Oesophagostomum and Bunostomum (Egerton et al., 1981; Gary and Kumar, 2007; Reinemeyer and Courtney, 2001) and also on Boophilus, Damalina and others arthropods (Barth and Preston, 1988; Borges et al., 2008; Colwell and Jacobsen, 2002; Lonneux et al., 1997; Marley et al., 1993; Reinemeyer and Courtney, 2001). According to findings of Sharma et al. (1990) the efficacy of ivermectin against Ascaridia galli infection was evaluated in chickens under controlled laboratory conditions. The chicks in the treated group were subcutaneously injected with ivermectin at a dose of 0.3 $\mathrm{mg} \mathrm{kg}{ }^{-1}$ body weight. The fall in post-treatment faecal egg counts was 81 and $92 \%$ in birds treated on Days 10 and 35, respectively. The drug was found to be 90 and 95\% effective against immature and adult worms, respectively. The lower lesion score and post-treatment near-normal haematobiochemical picture in treated 
birds confirmed these observations. The treated birds also had a better growth rate than the untreated chickens. The mature worms in the intestinal lumen of the host were more sensitive to the treatment than the immature stages of the parasite in the tissue phase (Bhat and Hemaprasanth, 1990). In present study, the drug effect was observed 28 days after treatment by pour on Ivermectin administration on Heterakis gallinarum $99.57 \%$ determined. In study by Sharma et al. (1990) indicated which drug has protective effect on chicks infected with Ascaridia galli (Bhat and Hemaprasanth, 1990), but in poultry any research was not done about Heterakis gallinarum. In other study by Williams et al. (1999) on comparison the effect of pour on administration of Ivermectin, Doramectin, Eprinomectin and Moxidectin, they observed that maximum and minimum effect was with Eprinomectin and Ivermectin respectively (Williams et al., 1999). Gayrard et al. (1999) proved that Ivermectin and Doramectin could be successfully used for control of gastrointestinal parasites in cattle (Gayrard et al., 1999). Whang et al. (1994) reported which pour on and injection administration of Moxidectin has positive effect more than $90 \%$ on gastrointestinal nematodes and significant different between these two types of administration were not reported (Whang et al., 1994). In two studies by Williams et al. (1996) indicated that Moxidectin has very important role for control of parasitic diseases (Williams et al., 1996; Williams and DeRosa, 2003). Skogerboe et al. (1999) and Rehbein et al. (1999) reported that pour on administration of Ivermectin during rain has antiparasitic effect more than $90 \%$ and rain has not specific effect on reduction the role of Ivermectin (Rehbein et al., 1999; Rolfe and Dawson, 1997; Skogerboe et al., 1999). In fact pour on administration of Ivermectin is very easy for farmers and so far, any specific side effects of Ivermectin administration have not been reported (Hooke et al., 1997; Reinemeyer and Courtney, 2001). Collectively, Ivermectin is very effective drug for control of gastrointestinal parasites in animals and its use is very easy and has not need specific tools. Effect of pour on administration of Ivermectin on other helminths and arthropods needs more studies.

\section{CONCLUSION}

The effect of Ivermectin pour-on against Heterakis gallinarum resulted in reduction in egg count exceeded $98 \%(p<0.05)$, so this drug can be used in antiparasitic program in poultry. Further investigations are necessary to evaluate the drug effect on other nematodes and parasitic infections.

\section{REFERENCES}

Aguirre, D.H., A.B. Gaido, M.M. Cafrune, M.E. Castelli and A.J. Mangold et al., 2005. Eprinomectin pour-on for control of Boophilus microplus (Canestrini) ticks (Acari: Ixodidae) on cattle. Veterinary Parasitol., 127: 157-163. DOI: 10.1016/j.vetpar.2004.09.027

Barth, D. and J.M. Preston, 1988. Efficacy of topically administered ivermectin against chorioptic and sarcoptic mange of cattle. Vet Rec., 123: 101-104. PMID: 3413951

Bhat, S.R.L. and T.K. Hemaprasanth, 1990. Anthelmintic activity of ivermectin against experimental Ascaridia galli infection in chickens. Vet. Parasitol., 37: 307-314. PMID: 2267731

Borges, F.A., H.C. Silva, C. Buzzulini, V.E. Soares and E. Santos et al., 2008. Endectocide activity of a new long-action formulation containing $2.25 \%$ ivermectin $+1.25 \%$ abamectin in cattle. Veterinary Parasitol., 155: 299-307. DOI: 10.1016/j.vetpar.2008.04.019

Colwell, D.D. and J.A. Jacobsen, 2002. Persistence activity of topical ivermectin against artificial infestation with hypodermal lineatum (Diptera: Ostridae). Vet Parasitol., 105: 247-256. PMID: 11934464

Egerton, J., C. Eary and D. Suhayda, 1981. The anthelmintic efficacy of ivermectin in experimental infected cattle. Vet parasitol., 8: 59-70. DOI: 10.1016/0304-4017(81)90018-2.

Gary, R. and R.R. Kumar, 2007. Duration of anthelmintic effect of three formulations of Ivermection (oral, injectable and pour-on) against multiple anthelmintic-resistant haemonchuscontortus in sheep. Vet Res. Commun., 165-7380. PMID: 17237985

Gayrard, V., M. Alvinerie and P.L. Toutain, 1999. Comparison of pharmacokinetic profiles of doramectin and ivermectin pour-on formulations in cattle. Vet. Parasitol., 81: 47-55. PMID: 9950328.

Georgi, J.R. and M.E. Georgi, 1990. Parasitology for Veterinarians. 5th Edn., WB Saunders Company, ISBN: 0721692834, pp: 3-5.

Hooke, F.G., P. Clement, D. Dell'Osa, R.M. Porter and D. MacColl et al., 1997. Therapeutic and protective efficacy of doramectin injectable against gastrointestinal nematodes in cattle in New Zealand: A comparison with moxidectin and invermectin pour-on formulations. Vet. Parasitol., 72: 43-51. PMID: 9403976 
Kassai, T., 1999. Veterinary Helminthology. 1st Edn., BH (Butterworth Heinemann), ISBN: 0750635630, pp: 13-19.

Lonneux, J.F., T.Q. Nguyen and B.J. Losson, 1997. Efficacy of pour-on and injectable formulations of moxidectin and ivermectin in cattle naturally infected with Psoroptesovis: Parasitological, clinical and serological data. Vet. Parasitol., 69: 319-330. PMID: 9195741

Lund, E.E. and A.M. Chute, 1974. The reproductive potential of Heterakis gallinarum in various species of galliform birds: Implications for survival of $\mathrm{H}$. gallinarum and Histomonas meleagridis to recent times. Int. J. Parasitol., 4: 455-461. DOI: 10.1016/0020-7519(74)90061-7

Mandal, S.C., 2006. Veterinary Parasitology at a Glance. 1st Edn, IBDC (International Book Distributing Company), ISBN: 8181891163, pp: 161.

Marley, S.E., R.D. Hall and R.M. Corwin, 1993. Ivermectin cattle pour-on: Duration of a single late spring treatment against horn flies, Haematobiairritans (L.) (Diptera: Muscidae) in Missouri, USA. Vet. Parasitol., 51: 167-172. PMID: 8128583

Rehbein, S., R.A. Barrick, A.F. Batty, M.D. Drag and P.F. Rolfe et al., 1999. Evaluation of the effect of simulated rainfall on the ef $\mathrm{R}$ cacy of Ivomec Pouron against Cooperia spp. infection in cattle. Parasitol. Res., 85: 783-786. PMID: 10431750

Reinemeyer, C.R. and C.H. Courtney, 2001. Antinematodal Drugs, Section 11, Chemotherapy of Parasitic Diseases. In: Veterinary Pharmacology and Therapeutics, Adams, H.R., Iowa State University Press/Ames, ISBN: 0813817439, pp: 963- 971.

Rolfe, P.F. and K.L. Dawson, 1997. Efficacy of topical ivermectin following exposure of treated cattle to rains. Vet. Rec., 141: 269-270. PMID: 9316241

Sharma, R.L. and T.K. Bhat and Hemaprasanth, 1990. Anthelmintic activity of ivermectin against experimental Ascaridia galli infection in chickens. Vet. Parasitol., 37: 307-314. PMID: 2267731
Skogerboe, T.L., V.C. Cracknell, D.J. Walstrom, L. Ritzhaupt and V.K. Karle, 1999. The effect of simulated rainfall on the efficacy of doramectin pour-on against nematode parasites of cattle. Vet. Parasitol., 86: 229-234. PMID: 10536979

Soulsby, E.J.L., 1986. Helminths, Arthropods and Protozoa of Domesticated Animals. 7th Edn., BailliereTindall, London, ISBN: 0812107802, pp: 1-4.

Urquhart, G.M., J. Armour, J.L. Duncan, A.M. Dunn and F.W. Jennings, 2003 Veterinary Parasitology. 2nd Edn., Book Power, Blackwell Science, ISBN: 0582229804, pp: 26-27

Vermunt, J.J., D.M. West and W.E. Pomroy, 1995. Multiple resistance to ivermectin and oxfendazole in Cooperia species of cattle in New Zealand. Vet. Rec., 137: 43-45. PMID: 8525583

Whang, E.M., C. Bauer, D. Kollmann and H.J. Bürger, 1994. Efficacy of two formulations ('injectable' and 'pour on') of moxidectin against gastrointestinal nematode infections in grazing cattle. Vet. Parasitol., 51: 271-281. PMID: 8171830

Williams, J.C. and A. DeRosa, 2003. Dose confirmation of moxidectin $0.5 \%$ pour-on against adults and fourth-stage larvae of various Cooperia spp. and Trichostrongylus colubriformis in Louisiana. Vet. Parasitol., 114: 295-303. PMID: 12809755

Williams, J.C., A.F. Loyacano, A. DeRosa, J. Gurie and B.C. Clymer et al., 1999. A comparison of persistent anthelmintic efficacy of topical formulations of doramectin, ivermectin, eprinomectin and moxidectin against naturally acquired nematode infections of beef calves. Vet. Parasitol., 85: 277-288. PMID: 10488730

Williams, J.C., A.F. Loyacano, A. DeRosa, J. Gurie and D.F. Coombs et al., 1997. A comparison of the efficacy of two treatments of doramectin injectable, ivermectin injectable and ivermectin pour-on against naturally acquired gastrointestinal nematode infections of cattle during a winterspring grazing season. Vet. Parasitol., 72: 69-77. PMID: 9403978

Williams, J.C., S.D. Broussard and G.T. Wang, 1996. Efficacy of moxidectin pour-on against gastrointestinal nematodes and Dictyocaulus viviparus in cattle. Vet. Parasitol., 64: 277-283. PMID: 8893482 